\title{
Weeds and endangered herbs have unforeseen dispersal helpers in the agri- environment: gastropods and earthworms
}

\author{
Manfred Türke ${ }^{1, \star}$, Tamara Blattmann², Eva Knop ${ }^{2}$, Anne Kindermann ${ }^{1}$, Julia Prestele ${ }^{3,4}$, \\ Leonardo Marquez ${ }^{5}$, Nico Eisenhauer ${ }^{1,6}$ and Christina Fischer ${ }^{7}$ \\ ${ }^{1}$ Research Department Ecology and Ecosystem Management, Terrestrial Ecology, Technische Universität \\ München, Hans-Carl-von-Carlowitz-Platz 2, D-85354 Freising-Weihenstephan, Germany. \\ ${ }^{2}$ Institute of Ecology and Evolution, University of Bern, Baltzerstrasse 6, CH-3012 Bern, Switzerland. \\ ${ }^{3}$ Bavarian State Research Center for Agriculture ( $\left.L f L\right)$, Institute for Agro-Ecology, Organic Farming and Soil \\ Protection, Lange Point 12, D-85354 Freising-Weihenstephan, Germany. \\ ${ }^{4}$ Research Department Ecology and Ecosystem Management, Restoration Ecology, Technische Universität \\ München, Emil-Ramann-Strasse 6, D-85354 Freising-Weihenstephan, Germany. \\ ${ }^{5}$ Crop Protection Division, Philippine Rice Research Institute, Maligaya, Science City of Muñoz, \\ PH-3119 Nueva Ecija, Philippines. \\ ${ }^{6}$ Present address: Institute of Ecology, Friedrich-Schiller-University Jena, Dornburger Straße 159, \\ D-07743 Jena, Germany. \\ ${ }^{7}$ Research Department Ecology and Ecosystem Management, Landscape Ecology, Technische Universität \\ München, Emil-Ramann-Strasse 6, D-85354 Freising-Weihenstephan, Germany. \\ ${ }^{*}$ Corresponding author: manfred.tuerke@gmx.net
}

\begin{abstract}
Agri-environmental schemes involving organic farming or set-aside management aim at promoting biodiversity and restoring ecosystem functioning in agrarian landscapes. Application of pesticides in these crop fields is strongly regulated facilitating the spread of weeds but also allowing for the establishment of endangered herbs and a variety of animals. Recent studies found gastropods and earthworms to be legitimate dispersers of seeds of wild plants. We assumed that both groups also play a significant role in the spread and establishment of wild plants within crop fields. Therefore, we are conducting a series of experiments in three different study systems on (1) the role of earthworms and gastropods as dispersers of rare herbs and weeds in an organic rye field in Germany, (2) the seed feeding behavior of gastropods of plants sown in fallow ground in Switzerland, and (3) weed dispersal in irrigated rice fields by golden apple snails in the Philippines.
\end{abstract}

Key words: seed dispersal, slugs, snails, crop field, feeding trial

\section{Introduction}

In the course of agricultural intensification, farmland biodiversity has declined due to the decrease of seminatural habitats in agrarian landscapes and the increased application of pesticides and fertilizers, impairing a variety of ecosystem functions and services ${ }^{1}$. Different approaches of agri-environmental management have been found to successfully restore biodiversity ${ }^{2}$. Plant diversity that provides habitat and food for animals can be established at the border of crop fields by set-aside management, e.g. wildflower strips, or within crop fields. Common weeds and rare arable herbs both profit from non-intensive or organic farming. While rare herbs are sown intentionally to strengthen their populations, weeds will colonize fields reducing crop yield ${ }^{3}$. Seed dispersal is essential for the viability and competitiveness of arable plant populations ${ }^{4}$. Most arable plant species, however, lack obvious adaptations for dispersal and rely on gravity when shedding their seeds ${ }^{4}$, which permits very limited dispersal distances unless seeds are transported by $\operatorname{man}^{3}$. Recent research highlights the importance of so far 


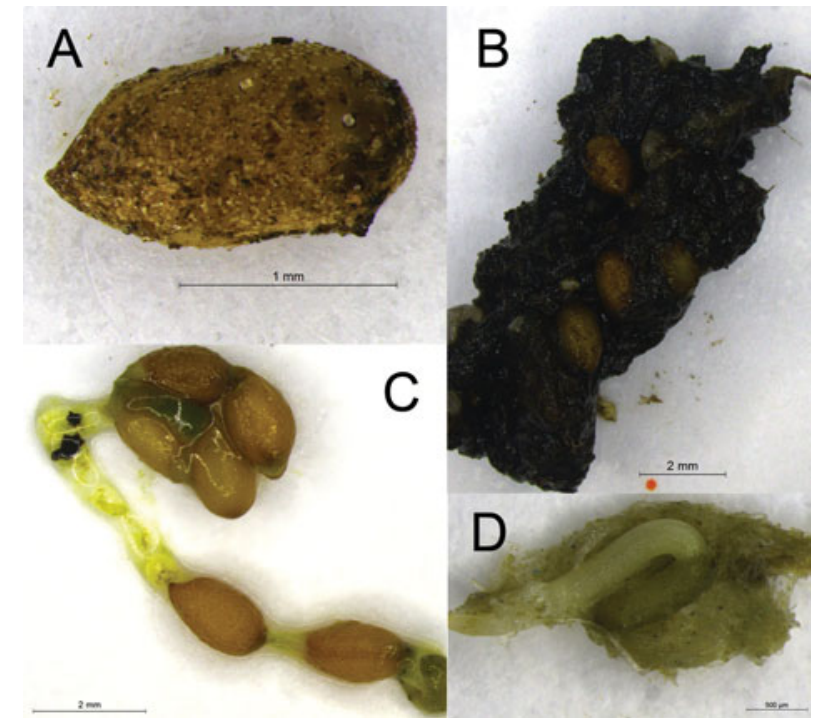

Figure 1. Seeds of field pansy (Viola arvensis) in (A, B) earthworm casts (Lumbricus terrestris) and in (C) slug feces (Arion lusitanicus), and (D) a seed of German chamomile (Matricaria recutita) germinating from slug feces.

underappreciated invertebrate taxa, in particular, gastropods $^{5}$ and earthworms ${ }^{6}$ in the dispersal of seeds of herbs. Also in crop fields or adjacent wild flower strips, gastropods were responsible for the removal of a fair proportion of weed or herb seeds $s^{7,8}$. We are conducting experiments within three projects to test the potential of gastropods, and partly also earthworms, to disperse seeds and also to predate on seeds of agricultural weeds and rare arable plants by the ingestion of seeds. In the following, we briefly present the three projects, their aims and first findings.

\section{The Projects}

\section{Weeds and rare herbs in an organic rye field (Germany)}

We established an organically managed rye field in Germany to assess the effects of management and animals on the establishment of rare arable wild herbs. A number of weeds are growing naturally in the field. We conducted seed removal experiments with five weeds and three rare herbs (Appendix 1) with one treatment accessible to all animals and one treatment protected against rodents. In addition, we used video cameras to identify all seedfeeding animals. In accompanying laboratory experiments, we offered seeds to two slug and two earthworm species of up to 15 plant species (animal speciesdependent), including 12 common weeds and three rare herbs (Appendix 1), followed by germination experiments. Slugs and earthworms readily swallowed seeds of different species and defecated them mostly apparently intact (Fig. 1). Seeds of several species germinated after

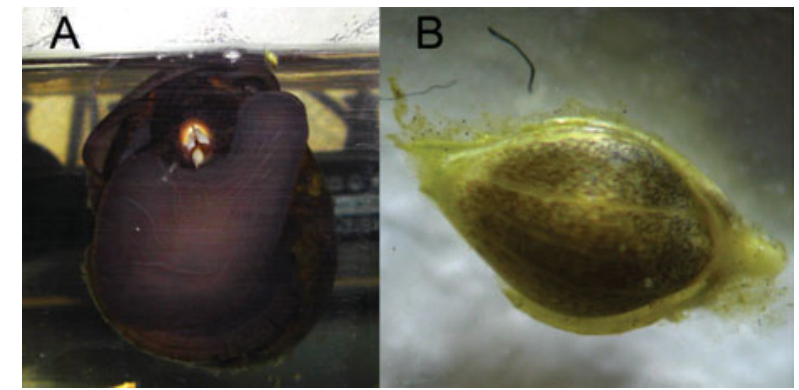

Figure 2. Seeds of common barnyard grass (Echinochloa crusgalli) (A) eaten by a golden apple snail (Pomacea canaliculata) and (B) collected from its feces.

being defecated. By screening the first videos, we observed rodents, carabids, earthworms and slugs visiting seed depots in the field, supporting the significance of interactions between seeds and the latter two invertebrate groups.

\section{Herbs sown in fallow ground (Switzerland)}

In a lab experiment, we fed four different gastropod species (Arion lusitanicus, Arion rufus, Cepaea nemoralis and Helix pomatia) with five different herb species often sown in fallow ground in Switzerland (Appendix 1). Consumption and damage of seeds after gut passage were assessed; defecated seeds were collected and put on soil to evaluate germination rates. We found high consumption rates in all mollusc species and for all five plant species. Furthermore, the seeds that had previously been defecated showed high germination rates, similar to those without gut passage. Our results therefore support our hypothesis that molluscs act as efficient and important seed dispersers of a wide range of plant species in agricultural landscapes.

\section{Weeds in irrigated rice fields (Philippines)}

Rice farmers in South-East Asia make a great effort to fight weeds. Exotic golden apple snails (Pomacea canaliculata) were introduced to control weeds in rice fields, amongst other things ${ }^{9}$. In most cases, however, the snails were a major pest, consuming rice plants ${ }^{9}$. We suggested that this invasive snail might also be spreading weeds in rice fields. Within the LEGATO project on land-use intensity and ecological engineering in irrigated rice (http://www.legato-project.net/), we collected seeds of 12 common weeds in the Philippines (Appendix 1), which currently are being offered to snails in feeding experiments. First observations in the laboratory showed that the snails readily consumed seeds of the troublesome barnyard grass Echinochloa crus-galli and defecated them apparently intact (Fig. 2). We will further conduct seed removal experiments and observations in rice fields in the Philippines. 


\section{Outlook}

Our complementary experiments in multiple settings will help us to understand whether gastropods and earthworms are important for weed movement and the establishment of sown plants in the agri-environment. Based on our findings, it is possible that invertebrates such as slugs that dwell in planted wild flower strips might affect crop yields negatively if they transport weeds into the fields, even if they do not feed on the crop. Thus, it might be valuable to establish structured habitats at crop margins which do not promote these invertebrates but their predators. In environments where seed dispersal is beneficial, such as in ecological restoration, knowing which seed traits encourage dispersal, and which animals are important in dispersal, would be beneficial. In consideration of our preliminary results, we suggest that future research on weed ecology, dispersal and predation should take these invertebrate groups into account.

\section{References}

1 Tscharntke, T., Klein, A.M., Kruess, A., Steffan-Dewenter, I., and Thies, C. 2005. Landscape perspectives on agricultural intensification and biodiversity-ecosystem service management. Ecology Letters 8:857-874.

2 Batary, P., Andras, B., Kleijn, D., and Tscharntke, T. 2011. Landscape-moderated biodiversity effects of agri-environmental management: a meta-analysis. Proceedings of the Royal Society B-Biological Sciences 278:1894-1902.

3 Liebman, M., Mohler, C.L., and Staver, C.P. 2001. Ecological Management of Agricultural Weeds. Cambridge University Press, Cambridge, UK.

4 Benvenuti, S. 2007. Weed seed movement and dispersal strategies in the agricultural environment. Weed Biology and Management 7:141-157.

5 Türke, M., Andreas, K., Gossner, M.M., Kowalski, E., Lange, M., Boch, S., Socher, S.A., Müller, J., Prati, D., Fischer, M., Meyhöfer, R., and Weisser, W.W. 2012. Are gastropods, rather than ants, important dispersers of seeds of myrmecochorous forest herbs? American Naturalist 179:124-131.

6 Forey, E., Barot, S., Decaens, T., Langlois, E., Laossi, K.-R., Margerie, P., Scheu, S., and Eisenhauer, N. 2011. Importance of earthworm-seed interactions for the composition and structure of plant communities: a review. Acta OecologicaInternational Journal of Ecology 37:594-603.

7 Fischer, C., Thies, C., and Tscharntke, T. 2011. Mixed effects of landscape complexity and farming practice on weed seed removal. Perspectives in Plant Ecology Evolution and Systematics 13:297-303.

8 Kollmann, J. and Bassin, S. 2001. Effects of management on seed predation in wildflower strips in northern Switzerland. Agriculture, Ecosystems and Environment 83:285-296.

9 Joshi, R.C. and Sebastian, L.S. (eds). 2006. Global Advances in Ecology and Management of Golden Apple Snails. Philippine Rice Research Institute, Munoz, Philippines. 
Appendix 1. Plant species of which seeds were/will be offered in field seed removal experiments (= Field) or to gastropods and earthworms in laboratory feeding trials (= Laboratory).

\begin{tabular}{|c|c|c|c|c|c|c|}
\hline Project & Plant species & & Common name & Family & Laboratory $^{1}$ & Field $^{1}$ \\
\hline \multirow[t]{15}{*}{ Germany } & Alopecurus myosuroides & Huds. & $\begin{array}{l}\text { Slender meadow } \\
\text { foxtail }\end{array}$ & Poaceae & AL, LT, DV & \\
\hline & Apera spica-venti & (L.) P. Beauv. & Silky bent grass & Poaceae & AL, LT, DV & \\
\hline & Capsella bursa-pastoris & (L.) Medik. & Shepherd's purse & Brassicaceae & $\mathrm{AL}, \mathrm{LT}, \mathrm{DV}$ & \\
\hline & Cirsium arvense & (L.) Scop. & Creeping thistle & Asteraceae & $\begin{array}{l}\text { AL, DR, LT, } \\
\text { DV }\end{array}$ & Yes \\
\hline & Consolida regalis & S.F. Gray & Forking larkspur & Ranunculaceae & $\mathrm{AL}, \mathrm{LT}, \mathrm{DV}$ & Yes \\
\hline & Elymus repens & (L.) Gould s. str. & Cough grass & Poaceae & AL, LT, DV & \\
\hline & Galium aparine & L. & Cleavers & Rubiaceae & AL, LT, DV & Yes \\
\hline & Legousia speculum-veneris & (L.) Chaix & Venus' looking glass & Campanulaceae & $\begin{array}{l}\mathrm{AL}, \mathrm{DR}, \mathrm{LT}, \\
\mathrm{DV}\end{array}$ & Yes \\
\hline & Lithospermum arvense & $\begin{array}{l}\text { (L.) } \\
\text { I. M. Johnst. }\end{array}$ & Field gromwell & Boraginaceae & AL, LT, DV & Yes \\
\hline & Matricaria recutita & L. & German chamomile & Asteraceae & AL, LT, DV & \\
\hline & Poa trivialis & L. & Rough bluegrass & Poaceae & AL, LT, DV & \\
\hline & Stellaria media & (L.) Vill. & Common chickweed & Caryophyllaceae & $\begin{array}{l}\mathrm{AL}, \mathrm{DR}, \mathrm{LT}, \\
\mathrm{DV}\end{array}$ & Yes \\
\hline & Thlaspi arvense & L. & Field penny-cress & Brassicaceae & $\begin{array}{l}\mathrm{AL}, \mathrm{DR}, \mathrm{LT}, \\
\mathrm{DV}\end{array}$ & Yes \\
\hline & $\begin{array}{l}\text { Tripleurospermum } \\
\text { perforatum }\end{array}$ & (Mérat) Lainz & Scentless chamomile & Asteraceae & $\mathrm{AL}, \mathrm{LT}, \mathrm{DV}$ & \\
\hline & Viola arvensis & Murray & Field pansy & Violaceae & $\begin{array}{l}\text { AL, DR, LT, } \\
\text { DV }\end{array}$ & Yes \\
\hline \multirow[t]{5}{*}{ Switzerland } & Valerianella locusta & L. & Corn salad & Valerianaceae & $\begin{array}{l}\mathrm{AL}, \mathrm{AR}, \mathrm{CN}, \\
\mathrm{HP}\end{array}$ & \\
\hline & Melilotus albus & (L.) Medik. & Honey clover & Fabaceae & $\begin{array}{l}\mathrm{AL}, \mathrm{AR}, \mathrm{CN}, \\
\mathrm{HP}\end{array}$ & \\
\hline & Brassica napus & L. & Rapeseed & Brassicaceae & $\begin{array}{l}\mathrm{AL}, \mathrm{AR}, \mathrm{CN}, \\
\mathrm{HP}\end{array}$ & \\
\hline & Agrostemma githago & L. & Common corncockle & Caryophyllaceae & $\begin{array}{l}\mathrm{AL}, \mathrm{AR}, \mathrm{CN}, \\
\mathrm{HP}\end{array}$ & \\
\hline & Camelina sativa & L. Crantz & False flax & Brassicaceae & $\begin{array}{l}\mathrm{AL}, \mathrm{AR}, \mathrm{CN}, \\
\mathrm{HP}\end{array}$ & \\
\hline \multirow[t]{12}{*}{ Philippines } & Chloris barbata & Steud. & Swollen finger grass & Poaceae & $(\mathrm{PC})$ & (?) \\
\hline & Cyperus iria & L. & Rice flat sedge & Cyperaceae & $(\mathrm{PC})$ & (?) \\
\hline & Digitaria ciliaris & (Retz.) Koel. & Crab grass & Poaceae & $(\mathrm{PC})$ & (?) \\
\hline & Echinochloa crus-galli & (L.) P. Beauv. & Barnyard grass & Poaceae & $\mathrm{PC}$ & (Yes) \\
\hline & Echinochloa glabrescens & $\begin{array}{l}\text { Munro ex } \\
\text { Hook. f. }\end{array}$ & Barnyard grass & Poaceae & $(\mathrm{PC})$ & $(?)$ \\
\hline & Eleusine indica & (L.) Gaertn. & Goose grass & Poaceae & $(\mathrm{PC})$ & (?) \\
\hline & Heliotropium indicum & L. & Indian heliotrope & Boraginaceae & (PC) & (?) \\
\hline & Ischaemum rugosum & Salisb. & Wrinkled grass & Poaceae & (PC) & (?) \\
\hline & Leptochloa chinesis & (L.) Nees & Chinese sprangletop & Poaceae & $(\mathrm{PC})$ & (?) \\
\hline & Ludwigia octovalvis & (Jacq.) Raven & $\begin{array}{l}\text { Longfruited } \\
\text { primrose-willow }\end{array}$ & Onagraceae & (PC) & $(?)$ \\
\hline & Paspalidium flavidum & $\begin{array}{l}\text { (Retz.) } \\
\text { A. Camus }\end{array}$ & $\begin{array}{l}\text { Yellow watercrown } \\
\text { grass }\end{array}$ & Poaceae & $(\mathrm{PC})$ & $(?)$ \\
\hline & Sphenoclea zeylanica & Gaertn. & Gooseweed & Campanulaceae & $(\mathrm{PC})$ & $(?)$ \\
\hline
\end{tabular}

Gastropods: AL = Spanish slug (Arion lusitanicus Mabille; syn.: Arion vulgaris Moquin-Tandon), DR = Grey field slug (Deroceras reticulatum O.F. Müller), AR = Red slug (Arion rufus L.), $\mathrm{CN}=$ Grove snail (Cepaea nemoralis $\mathrm{L}$.), HP= Roman snail (Helix pomatia L.), PC=Golden apple snail (Pomacea canaliculata Lamarck). Earthworms: LT = common earthworm (Lumbricus terrestris L.), DV = European nightcrawler (Dendrobaena veneta Rosa; syn.: Eisenia hortensis Michaelsen).

${ }_{1}$ Parentheses indicate that experiments are planned. 